\title{
Bacillus spp. isolates for the control of Meloidogyne incognita in common bean
}

\author{
Isolados de Bacillus spp. no controle de Meloidogyne incognita na cultura \\ do feijoeiro
}

\section{Rafael Henrique FERNANDES'; Everaldo Antônio LOPES²; Amanda Ferreira BONTEMPO'; Cícero Augusto Guimarães FUGA ${ }^{1}$; Bruno Sérgio VIEIRA ${ }^{3}$}

\begin{abstract}
${ }^{1}$ Programa de Pós-Graduação em Produção Vegetal, Instituto de Ciências Agrárias, Universidade Federal de Viçosa, Campus de Rio Paranaíba. Rodovia MG 230, km 07, Caixa Postal 22, 38810-000, Rio Paranaíba - MG. E-mails: rafael.fernandes@ufv.br, amanda.bontempo@ufv.br, cicero.fuga@nooabrasil.com.br

${ }^{2}$ Autor para correspondência. Programa de Pós-Graduação em Produção Vegetal, Instituto de Ciências Agrárias, Universidade Federal de Viçosa, Campus de Rio Paranaíba. Rodovia MG 230, km 07, Caixa Postal 22, 38810-000, Rio Paranaíba - MG. E-mail: everaldolopes@ufv.br

${ }^{3}$ Universidade Federal de Uberlândia, Campus de Monte Carmelo, Rodovia LMG 746, km 01, Bloco 1 AMC, 38500-000, Monte Carmelo - MG. E-mail: brunovieira@iciag.ufu.br
\end{abstract}

Recebido em: 02-03-2018; Aceito em: 10-04-2018

\begin{abstract}
The objective of this work was to evaluate the effect of Bacillus spp. isolates on the control of Meloidogyne incognita in greenhouse and field experiments. In the greenhouse, isolates 57 (Bacillus sp.), 63 (Bacillus amyloliquefaciens), SF 194 (Bacillus sp.), SF 203 (Bacillus amyloliquefaciens), and a mixture containing the four isolates were applied to the soil surface ( $\left.2 \mathrm{~L} \mathrm{ha}^{-1}, 1 \times 10^{9} \mathrm{cfu} \mathrm{mL}^{-1}\right)$, infested with 5,000 eggs of $M$. incognita. Sixty days after planting, the mass of the bean roots and the number of galls and eggs were evaluated. In a field naturally infested with $M$. incognita, the effects of isolates 57,63 , and a mixture containing both of them were observed after application to the soil surface $\left(2 \mathrm{~L} \mathrm{ha}^{-1}\right)$, with or without seed treatment with the isolates $\left(2 \mathrm{~mL} \mathrm{~kg}^{-1}\right)$. Production, thousand-grain weight, reproductive factor, and number of eggs were evaluated at 90 days after planting. In the greenhouse, the application of the isolates did not influence neither root biomass, nor the number of galls and eggs. In the field, the application of isolates 57,63 , and the mixture $57+63$ on the soil surface and in seed treatment did not increase total production and thousand-grain weight, nor did it reduce the nematode multiplication in the soil and in the roots of the plants. Thus, Bacillus spp. isolates 57, 63, SF 194, and SF 203 have no potential to formulate bionematicides for the control of $M$. incognita in common bean.
\end{abstract}

Additional keywords: biological control, Phaseolus vulgaris, root-knot nematode.

\begin{abstract}
Resumo
O objetivo deste trabalho foi avaliar o efeito de isolados de Bacillus spp. no controle de Meloidogyne incognita em casa de vegetação e em campo. Em casa de vegetação, os isolados 57 (Bacillus sp.), 63 (Bacillus amyloliquefaciens), SF 194 (Bacillus sp.), SF 203 (Bacillus amyloliquefaciens) e uma mistura contendo os quatro isolados foram aplicados na superfície do solo (2 $\mathrm{L} \mathrm{ha}{ }^{-1}, 1 \times 10^{9}$ ufc $\left.\mathrm{mL}^{-1}\right)$ infestado com 5.000 ovos de M. incognita. Após 60 dias do plantio, a massa das raízes de feijoeiro e os números de galhas e ovos foram avaliados. Em campo naturalmente infestado com M. incognita, avaliaram-se os efeitos dos isolados 57; $63 \mathrm{e}$ uma mistura contendo os isolados 57 e 63, aplicados na superfície do solo $\left(2 \mathrm{~L} \mathrm{ha}^{-1}\right)$, com ou sem o tratamento de sementes com os isolados $\left(2 \mathrm{~mL} \mathrm{~kg}^{-1}\right)$. A produção e a massa de mil grãos, o fator de reprodução e o número de ovos foram avaliados aos 90 dias após o plantio. Em casa de vegetação, a aplicação dos isolados não influenciou a biomassa das raízes e o número de galhas e de ovos. Em campo, a aplicação dos isolados 57; 63 e a mistura $57+63$ na superfície do solo e em tratamento de sementes não aumentaram a produção total e a massa de mil grãos, tampouco reduziram a multiplicação do nematoide no solo e nas raízes das plantas. Assim, os isolados 57; 63; SF 194 e SF 203 de Bacillus spp. não possuem potencial para formulação de bionematicidas para o controle de $M$. incognita em feijoeiro.
\end{abstract}

Palavras-chave adicionais: controle biológico, nematoide de galhas, Phaseolus vulgaris.

\section{Introduction}

The occurrence of diseases is one of the main factors related to the low yield of common bean
(Phaseolus vulgaris L.) in Brazil. Among the soil pathogens that parasitize the crop, nematode species Meloidogyne incognita (Kofoid \& White) Chitwood, Meloidogyne javanica (Treub) Chitwood, and 
Meloidogyne arenaria (Neal) Chitwood are responsible for extensive damage to crops in South America, Africa, and Asia (Sikora et al., 2005).

It should be noted that there is only one nematicide registered in Brazil for the control of rootknot nematode in common bean, and it is classified as extremely toxic (MAPA, 2018). Few cultivars, like Aporé and Talimã, have some degree of resistance to M. incognita (Ferreira et al., 2010). The sustainable management of this pathogen in the crop depends mainly on cultural, physical, and biological methods. Bacillus species have been used for leaf and soil pathogen control. This genus belongs to the group of grampositive bacteria, whose characteristic is the production of heat-resistant endospores (Ann, 2013). The formation of resistant spores is a desirable feature for a biocontrol agent, since it provides greater field survival and longer shelf life to products formulated therefrom. In addition, Bacillus-based products are more environmentally safe than chemicals, and are compatible with conventional farming practices (Chen \& Dickinson, 2004).

Different Bacillus species can be used in the management of plant-parasitic nematodes, for example, Bacillus thuringiensis Berliner, Bacillus laterosporus Laubach, Bacillus circulans Jordan, Bacillus subtilis Cohn, Bacillus pumilus Meyer \& Gottheil, Bacillus cereus Frankland \& Frankland, Bacillus sphaericus Neide, and Bacillus licheniformis (Weigmann) Chester (Kavitha et al., 2007; Lian et al., 2007; Tian et al., 2007; Mohammed et al., 2008; Araújo \& Marchesi, 2009; Ann, 2013). The mechanisms of action of these bacteria against nematodes involve the production of nematotoxic substances, modification of root exudates of host plants, systemic resistance induction, and production of lethal proteases within the gut following the ingestion of the bacteria by the nematode (Araújo et al., 2002; Kavitha et al., 2007; Lian et al., 2007; Tian et al., 2007; Mohammed et al., 2008; Niu et al., 2010; Ann, 2013).

Considering the potential of Bacillus spp. isolates in the control of nematodes, and the perspective of bionematicide development from these antagonists, the objective of this study was to evaluate the effect of these isolates on the control of $M$. incognita in bean plants grown under greenhouse and field conditions.

\section{Material and methods}

\section{Greenhouse experiment}

For the greenhouse experiment, the nematode inoculum was multiplied and maintained in roots of tomato cv. Santa Clara grown in pots containing a mixture of soil and sand (1:1, v:v), previously autoclaved at $120^{\circ} \mathrm{C}$ for $2 \mathrm{~h}$. Isolates 57 (Bacillus sp.) and 63 (Bacillus amyloliquefaciens), obtained from bean rhizosphere soils, were kept at $4^{\circ} \mathrm{C}$ in a refrigerator, preserved by means of the mineral oil technique (Alfenas \& Mafia, 2007), and are part of the microbiological collection of the Laboratory of Microbiology and
Phytopathology of the University Center of Patos de Minas (UNIPAM). Moreover, isolates SF 194 (Bacillus sp.) and SF 203 (Bacillus amyloliquefaciens), provided by the Farroupilha Laboratory (Grupo Farroupilha, Patos de Minas - MG), and a formulation containing the mixture of the four isolates were also included in the experiment. The bacterial concentration in the formulations was $1 \times 10^{9}$ colony forming units (cfu) $\mathrm{mL}^{-1}$.

Tomato roots showing galls and egg masses were collected 60 days after inoculation for nematode egg extraction, following a technique described by Hussey \& Barker (1973) and modified by Boneti \& Ferraz (1981). The inoculum concentration was adjusted with the aid of a Peters chamber to 2500 eggs $\mathrm{mL}^{-1}$.

The bacterial isolates were cultured in 250-mL Erlenmeyer flasks containing $50 \mathrm{ml}$ of MSF liquid culture medium (2.5 g NaCl; $2 \mathrm{~g} \mathrm{KH}_{2} \mathrm{PO}_{4} ; 2.5 \mathrm{~g} \mathrm{~K}_{2} \mathrm{HPO}_{4}$; $0.25 \mathrm{~g} \mathrm{MgSO}_{4} 7 \mathrm{H}_{2} \mathrm{O} ; 0.1 \mathrm{~g} \mathrm{MnSO}_{4}$. $\mathrm{H}_{2} \mathrm{O} ; 5 \mathrm{~g}$ dextrose, and $4 \mathrm{~g}$ yeast extract in $1000 \mathrm{ml}$ water), and incubated at room temperature in an orbital shaker for $48 \mathrm{~h}$ under constant stirring (250 rpm). After the elapsed period, the culture medium containing the isolates was centrifuged for $15 \mathrm{~min}$ at $2000 \mathrm{~g}$ for the separation of the bacterial cells. Bacterial suspensions were adjusted to $1 \times 10^{9}$ cells $\mathrm{mL}^{-1}$, and maintained at $4^{\circ} \mathrm{C}$ until use. Specific procedures in the preparation of the formulations are not described because they are confidential to the Farroupilha Laboratory.

For the bean cultivation, 2-L plastic pots were filled with the mixture soil:sand $(1: 1, \mathrm{v}: \mathrm{v})$, previously autoclaved at $120 \stackrel{\circ}{C}$ for $2 \mathrm{~h}$. The soil of each pot was infested with 5,000 eggs of the nematode, and revolved aiming at the homogenization of the pathogen inoculum. Then, the bacterial suspensions or the MSF liquid culture medium were applied to the soil with the aid of a $\mathrm{CO}_{2}$ pressurized costal spray, at $3.02 \mathrm{kgf} \mathrm{cm}^{-2}$, equipped with a bar with two 11002 fan-type nozzles, spaced $0.5 \mathrm{~m}$ apart, with a syrup volume of $200 \mathrm{~L} \mathrm{ha}^{-1}$ and a suspension dose adjusted to $2 \mathrm{~L} \mathrm{ha}^{-1}$. Subsequently, $142 \mathrm{~mL}$ of sterilized water was applied to the soil surface of each pot, simulating rainfall or an irrigation depth equivalent to $5 \mathrm{~mm}$. The objective of this operation was to allow the percolation of the bacterial cells in the soil profile and to increase the direct contact with the eggs of the pathogen, without resulting in loss of the bacterial inoculum. Two days after soil infestation, three seeds of common bean cv. Pérola were sown in each pot. After the complete development of the primary leaf, the thinning of seedlings was performed, leaving only one seedling per pot.

The experiment was composed of eight treatments, including soil infested with $M$. incognita and treated with bacterial suspension containing one of the four isolates; soil infested with nematode and treated with the mixture of the four isolates; soil infested and treated only with the MSF culture medium; in addition to plots not treated with the bacteria, and with soil infested or not with nematode. The treatments were repeated five times and the pots containing one plant 
(plot) were arranged in a completely randomized design on benches. The experiments were conducted twice. At 60 days after sowing, the mass of shoots and roots of the plants were evaluated, besides the number of galls and nematode eggs per root system.

\section{Field experiment}

The potential of bacterial isolates 57 and 63 to control the nematode was also evaluated in an area naturally infested with $M$. incognita and destined to cereal planting, located in the Experimental Field of the University Center of Patos de Minas (UNIPAM), in Patos de Minas - MG. The altitude of the site is $800 \mathrm{~m}$. The municipality features a tropical climate of altitude, and rainfall ranging from 1,400 to $1,800 \mathrm{~mm}$, with regular rains from October to March, and dry season from April to September. Isolates SF 194 and SF 203 were not evaluated in the field due to the results of the greenhouse experiment, in which these isolates increased the nematode egg production in common bean.

The soil was tilled by means of two harrowings, followed by furrowing. Soil samples were collected from the area before the experiment was implemented (three simple samples per plot) to form a composite sample (500 g), which was used to quantify the nematode population, extracted by the method of centrifugal flotation in sucrose solution (Jenkins, 1964).

In this experiment, the liquid formulations containing isolates 57,63 , and the mixture of isolates 57 and 63 were studied, in addition to the application of water as a control treatment. The formulations were prepared according to the industrial protocol adopted by the Farroupilha Laboratory, and used in seed treatment and in the application to the soil surface. The experiment was set in a randomized complete block design, with treatments arranged in a subdivided plot design, with four replicates. The effect of the application of the formulations or water on the soil surface was studied in the plots, while the effect of seed treatment with the formulations or with water was evaluated in the subplots.

The experimental plot consisted of three planting rows of $3 \mathrm{~m}$ in length, spaced $0.8 \mathrm{~m}$ apart, and 36 plants spaced approximately $8 \mathrm{~cm}$ apart. Half of the seeds of bean cv. Pérola of each planting row were treated with bacterial formulations or with water (subplots), the other half remaining without any treatment. Bacterial formulations with a concentration of $1 \times 10^{9} \mathrm{cfu} \mathrm{mL}-1$ were mixed to the seeds at $2 \mathrm{~mL} \mathrm{~kg}^{-1}$, followed by sowing. The planting fertilization used was $300 \mathrm{~kg} \mathrm{ha}^{-1}$ of the formulated 08-28-16, according to the soil analysis.

After furrow closure, bionematicides or water were applied to the soil surface of the plots. The operation was carried out using a $\mathrm{CO}_{2}$ pressurized costal

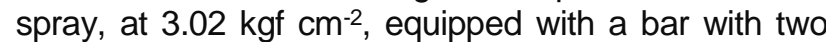
11002 fan-type nozzles, spaced $0.5 \mathrm{~m}$ apart, with a syrup volume of $200 \mathrm{~L} \mathrm{ha}^{-1}$ and a suspension dose adjusted to $2 \mathrm{~L} \mathrm{ha}^{-1}$ and concentration of $1 \times 10^{9} \mathrm{cfu} \mathrm{mL}^{-1}$.
The useful plot was represented by the central planting row, discarding $0.5 \mathrm{~m}$ at each end of the row.

The experiment was evaluated at the end of ninety days, with the collection of soil samples for the estimation of the final nematode population, analysis of yield and thousand-grain weight per plot (extrapolated per hectare), besides the removal of the root system of ten plants per subplot for quantification of the number of eggs produced by $M$. incognita in each plant. The extractions of juveniles from the soil and of eggs from the roots were carried out following the methods proposed by Jenkins (1964) and Boneti \& Ferraz (1981), respectively.

In both experiments, the data were submitted to analysis of variance by the $F$ test $(p<0.05)$, and significant differences between means were determined by Duncan's test $(p<0.05)$. In the greenhouse experiment, there was no significant interaction between experiment and treatments. Therefore, the data were analyzed together. The field experiment was conducted only once.

\section{Results and discussion}

\section{Greenhouse experiment}

The root mass of common bean cv. Pérola grown in soil treated both with isolates 57, SF 203, SF 194, and with their mixture was smaller than that of plants not inoculated with the nematode (Table 1). Plant growth promotion by Bacillus species depends on the isolate-host interaction. Most of the bacterial isolates found in the environment do not promote plant growth (Lugtenberg \& Kamilova, 2009). Some Bacillus strains are able to promote plant growth in different botanical families, such as tomato, bean, and okra (Dawar et al., 2008; Araújo \& Marchesi, 2009; Khan et al., 2010). However, other isolates do not stimulate the development of the same crops (Khan et al., 2010; Vaz et al., 2011; Fernandes et al., 2013). Therefore, the phenomenon of growth promotion by Bacillus species depends on the ability of the isolate to interact with the host and to induce the production of phytohormones, solubilize nutrients, increase nitrogen fixation and/or inhibit ethylene synthesis (Lugtenberg \& Kamilova, 2009). Thus, we can infer that isolates 57,63 , SF 203 , and SF 194 are not capable of stimulating plant growth in common bean.

None of the Bacillus isolates reduced the number of galls nor the number of eggs produced by $M$. incognita in the roots of the host plant compared to the application of the culture medium alone (Table 1). Similar to that observed in relation to growth promotion, we conclude that the four isolates studied are also not able to control $M$. incognita in common bean when applied to the soil. Contrary to expected, $M$. incognita egg production in roots of beans grown in plots treated with isolates SF 194 and SF 203 was approximately four times greater than in the control (Table 1). Future studies are needed to understand the mechanisms involved in the synergism between these isolates and 
M. incognita in common bean. The effect of Bacillus species on the activation of resistance mechanisms of the plant against phytopathogens is known (Fabry et al., 2007; Tian et al., 2007; Araújo \& Menezes, 2009;
Lugtenberg \& Kamilova, 2009). Notwithstanding, information on the possibility of Bacillus isolates contributing to limit plant resistance to nematodes is still scarce.

Table 1 - Mass of common bean roots cultivar Pérola, number of galls and eggs of Meloidogyne incognita per root system after the application of Bacillus spp. isolates suspension or MSF culture medium at 60 days after cultivating the plants in greenhouse.

\begin{tabular}{lccc}
\hline Treatment & Mass of roots $(\mathrm{g})$ & Number of galls & Number of eggs \\
\hline Isolate SF 203 & $10.12 \mathrm{~b}$ & $245 \mathrm{~b}$ & $66,080 \mathrm{a}$ \\
Isolate 63 & $12.66 \mathrm{~b}$ & $184 \mathrm{~b}$ & $38,850 \mathrm{ab}$ \\
Isolate 57 & $9.26 \mathrm{~b}$ & $89 \mathrm{~b}$ & $26,880 \mathrm{ab}$ \\
Isolate SF 194 & $6.80 \mathrm{~b}$ & $205 \mathrm{~b}$ & $66,150 \mathrm{a}$ \\
Mixture of isolates & $6.36 \mathrm{~b}$ & $165 \mathrm{~b}$ & $44,625 \mathrm{ab}$ \\
MSF culture medium & $14.53 \mathrm{~b}$ & $155 \mathrm{~b}$ & $28,088 \mathrm{ab}$ \\
Infested soil - Control & $14.07 \mathrm{~b}$ & $394 \mathrm{a}$ & $16,300 \mathrm{~b}$ \\
Non-infested soil - Control & $31.20 \mathrm{a}$ & - & - \\
\hline CV (\%) & 11.12 & 58.15 & 57.05 \\
\hline
\end{tabular}

Mean of five replicates. Means followed by the same letter within the column do not differ by the Duncan's test $(p<0.05)$.

\section{Field experiment}

The application of bacterial isolates 57 and 63 alone or in a mixture on the soil surface and/or in seed treatment did not increase total production and thousand-grain weight (Table 2), nor did it reduce nematode multiplication in the soil and in the roots of bean cultivar Pérola (Table 3). Crop yield ranged from 1,916 to $3,092 \mathrm{~kg} \mathrm{ha}^{-1}$ in the subplots. The reproductive factor of $M$. incognita in the soil was higher than 1 in all sub- plots, meaning that the pathogen population increased throughout the cycle of the legume, regardless of the application of the formulations on the surface and in seed treatment. The pathogen multiplication in the bean roots, represented by the mean number of eggs per plant, occurred without significant interference of the antagonist, ranging from $3,062.5$ to $9,765.0$ eggs per plant.

Table 2 - Estimated productivity $\left(\mathrm{kg} \mathrm{ha}^{-1}\right)$ and mass of one thousand grains of common bean cultivar Pérola after the use of treated seeds with suspension of Bacillus spp. isolates or non-treated seeds and soil application of water or formulations with the isolates on soil surface in a naturally infested with Meloidogyne incognita.

\begin{tabular}{|c|c|c|c|c|c|c|}
\hline \multirow{2}{*}{ Treatment of soil } & \multicolumn{3}{|c|}{ Grain productivity $\left(\mathrm{kg} \mathrm{ha}^{-1}\right)$} & \multicolumn{3}{|c|}{ One thousand-grain mass $(\mathrm{g})$} \\
\hline & NTS & TS & Mean & NTS & TS & Mean \\
\hline Isolate 57 & $2,058.1$ & $2,018.6$ & $2,038.3 \mathrm{~ns}^{+}$ & 238.1 & 213.4 & $225.8 \mathrm{~ns}^{+}$ \\
\hline Isolate 63 & $2,689.8$ & $2,356.4$ & $2,523.1$ & 235.2 & 218.8 & 227.0 \\
\hline Isolate 57 + Isolate 63 & $3,092.8$ & $1,916.3$ & $2,504.3$ & 280.3 & 201.8 & 241.1 \\
\hline Water (Control) & $2,526.7$ & $2,807.9$ & $2,667.3$ & 221.6 & 233.4 & 227.5 \\
\hline Mean & $2,591.8 \mathrm{~ns}^{*}$ & $2,274.8$ & - & $243.8 \mathrm{~ns}^{*}$ & 216.9 & - \\
\hline
\end{tabular}

Mean of four replicates; $\mathrm{ns}^{*}=$ no significant difference between treated seeds (TS) with bacterial formulations or water and Non-treated seeds (NTS) by F's test $(p>0.05)$. $\mathrm{ns}^{+}$no significant difference bacterial between bacterial isolates and water by F's test $(p>0.05)$.

Few studies were conducted under field conditions to evaluate the effect of Bacillus species on nematode control (Chen \& Dickinson, 2004), mainly in Brazil (Oliveira et al., 2015). Microbiostasis and variations in temperature, humidity, and soil microbiota population in the field can interfere with the dynamics of the antagonists and nematodes throughout the host crop cycle, leading to inefficiency of the isolates selected as promising under controlled conditions (Oliveira et al. 2015). In the present study, isolates 57 and 63 did not control $M$. incognita in the greenhouse experiment using sterilized soil and under controlled conditions. Thus, the effect of microbiostasis and abrupt environmental changes, potentially harmful to the antagonist, cannot explain the absence of nematode control. However, these isolates had been selected in the laboratory because of their ability to inhibit hatching and kill second-stage juveniles of the root-knot nematode (unpublished data), which encouraged us to study them under greenhouse and field conditions. 
Table 3 - Reproduction factor and number of eggs of Meloidogyne incognita in common bean cultivar Pérola after the use of treated seeds with suspension of Bacillus spp. isolates or non-treated seeds and soil application of water or formulations with the isolates on soil surface.

\begin{tabular}{lcccccc}
\hline \multirow{2}{*}{ Treatment of soil } & \multicolumn{3}{c}{ Reproduction factor* $^{*}$} & \multicolumn{3}{c}{ Number of eggs ${ }^{+, ~}$} \\
\cline { 2 - 7 } & NTS & TS & Mean & NTS & TS & Mean \\
\hline Isolate 57 & 1.20 & 1.09 & $1.14 \mathrm{~ns}^{+}$ & $3,062.5$ & $3,762.5$ & $3,412.5 \mathrm{~ns}^{+}$ \\
Isolate 63 & 1.06 & 1.13 & 1.23 & $4,112.5$ & $3,399.4$ & $3,755.9$ \\
Isolate 57 + Isolate 63 & 1.56 & 1.53 & 1.19 & $9,765.0$ & $3,062.5$ & $6,413.8$ \\
Water (Control) & 1.33 & 1.13 & 1.44 & $4,112.5$ & $7,262.5$ & $5,687.5$ \\
Mean & $1.29 \mathrm{~ns}^{*}$ & 1.22 & - & $5,263.1 \mathrm{~ns}^{*}$ & $4,371.7$ & - \\
\hline CV (\%) & \multicolumn{5}{c}{} \\
\hline
\end{tabular}

Means of four replicates. $\mathrm{ns}^{*}=$ no significant difference between treated seeds (TS) with bacterial formulations or water and Non-treated seeds (NTS) by F's test $(p>0.05)$. ns ${ }^{+}$no significant difference bacterial between bacterial isolates and water by F's test $(p>0.05)$. ${ }^{*}$ Reproduction factor $=$ Initial population/Final population of the nematode - number of juveniles per $100 \mathrm{~cm}^{-3}$ of soil. +Means values of number of eggs produced by nematode in ten plants per subplot. ${ }^{ \pm}$Data transformed to $\log _{10}(\mathrm{x})$.

The seed treatment strategy with Bacillus spp. was adopted in the field experiment to assure competitive advantage to the antagonist in the colonization of the roots, and to assure the control of nematodes, a fact that was not observed in the greenhouse when the bacterium was applied directly to the soil. The microbiolization of bean seeds with $B$. subtilis had already been reported as efficient in the control of $M$. incognita (Khan et al., 2007), but was not sufficient for the biocontrol in the present work. Further studies should be conducted to verify if these results occurred due to the inefficiency of the evaluated isolates in establishing themselves in the soil or because of the soil and environment conditions of the experiment.

\section{Conclusions}

Bacillus spp. isolates 57,63 , SF 194 , and SF 203 do not have potential to formulate bionematicides for the control of $M$. incognita in common bean.

\section{Acknowledgements}

The authors thank FAPEMIG for their financial support (Project APQ-1932-10), and the Farroupilha Laboratory and UNIPAM, both located in Patos de Minas (MG), for assisting in the development of the experiments.

\section{References}

Alfenas AC, Mafia RG (2007) Métodos em Fitopatologia. Editora UFV, Viçosa. 382p.

Ann YN (2013) Screening for nematicidal activities of Bacillus species against root knot nematode (Meloidogyne incognita). American Journal of Experimental Agriculture 3(4):794-805.

Araújo FF, Marchesi GVP (2009) Uso de Bacillus subtillis no controle da meloidoginose e na promoção do crescimento do tomateiro. Ciência Rural 39(5):1558-1561.
Araújo FF, Menezes D (2009) Indução de resistência a doenças foliares em tomateiro por indutores biótico (Bacillus subtilis) e abiótico (Acibenzolar-S-Metil). Summa Phytopathologica 35(3):169-172.

Araújo FF, Silva JFV, Araújo ASF (2002) Influência de Bacillus subtilis na eclosão, orientação e infecção de Heterodera glycines em soja. Ciência Rural 32(2):197202.

Boneti JIS, Ferraz S (1981) Modificação do método de Hussey \& Barker para extração de ovos de Meloidogyne exigua de raízes de cafeeiro. Fitopatologia Brasileira 6:553.

Chen S, Dickinson DW (2004) Biological control of nematodes with bacterial antagonists. In: Chen Z, Chen S, Dickinson DW. Nematology - Advances and perspectives: Nematode management and utilization, Tsinghua University Press \& CABI Publishing, cap. 21, p.1041-1082.

Dawar S, Tariq M, Zaki MJ (2008) Application of Bacillus species in control of Meloidogyne javanica (Treub) Chitwood on cowpea and mash bean. Pakistan Journal of Botany 40(1):439-444.

Fabry CFS, Freitas LG, Godinho MT, Neves WS, Ferraz S (2007) Resistência sistêmica a Meloidogyne javanica induzida por Rhizobium etli. Nematologia Brasileira 31(2):5-9.

Fernandes RH, Lopes EA, Vieira BS, Bontempo AF (2013) Controle de Meloidogyne javanica na cultura do feijoeiro com isolados de Bacillus spp. Revista Tropica: Ciências Agrárias e Biológicas 7(1):76-81.

Ferreira S, Gomes LAA, Maluf WR, Campos VP, Carvalho Filho JLS, Santos DC (2010) Resistance of common bean and snap bean cultivars to root-knot nematodes. Hortscience 45(2):320-322. 
Hussey RS, Barker KR (1973) A comparison of methods of collecting inocula of Meloidogyne spp. including a new technique. Plant Disease Reporter 57:10251028.

Jenkins WR (1964) A rapid centrifugal-flotation technique for separating nematodes from soil. Plant Disease Reporter 48: 692.

Kavitha J, Jonathan EI, Umamaheswari R (2007) Field application of Pseudomonas fluorescens, Bacillus subtilis and Trichoderma viride for the control of Meloidogyne incognita in sugarbeet. Journal of Biological Control 21(2):211-215.

Khan MR, Khan SM, Mohiddin FA, Askary TH (2007) Effect of certain phosphate-solubilizing bacteria on root-knot nematode disease of mungbean. Development in Plant and Soil Sciences 102:341-346.

Khan MQ, Wassem MA, Zaki MJ, Khan SA (2010) Evaluation of Bacillus thuringiensis isolates against root-knot nematodes following seed application in okra and mungbean. Pakistan Journal of Botany 42(4):2903-2910.

Lian LH, Tian BY, Xiong MZ, Zhu MZ, Xu J, Zhang KQ (2007) Proteases from Bacillus: A new insight into the mechanism of action for rhizobacterial suppression of nematode populations. Letters in Applied Microbiology 45(3):262-269.

Lugtenberg B, Kamilova F (2009) Plant-growth-promoting rhizobacteria. Annual Review of Microbiology 63:541-556.

MAPA - Ministério da Agricultura, Pecuária e Abastecimento (2018) Sistema de Agrotóxicos Fitossanitários (AGROFIT). Disponível em: $<$ http://extranet.agricultura.gov.br/agrofit_cons/principal _agrofit_cons>. Acesso em 01 de mar. 2018.
Mohammed SH, Anwer M, Saedy E, Mohamed R, Enan N, Ibrahim E, Ghareeb A, Salah AM (2008) Biocontrol efficiency of Bacillus thuringiensis toxins against root-knot nematode, Meloidogyne incognita. Journal of Cell and Molecular Biology 7(1):57-66.

Niu Q, Huang X, Zhang L, Xu J, Yang D, Wei K, Niu X, An Z, Bennett JW, Zou C, Yang J, Zhang KQ (2010) A Trojan horse mechanism of bacterial pathogenesis against nematodes. Proceedings of the National Academy of Sciences of the United States of America 107(38):16631-16636.

Oliveira TF, Fernandes $\mathrm{RH}$, Costa RL, Lopes EA (2015) Formulation of bionematicides based on bacteria for the control of the lesion nematode in common bean. Idesia 31(1):147-150.

Sikora RA, Greco N, Silva JFV (2005) Nematodes parasites of food legumes. In: Luc M, Sikora RA, Bridge $\mathrm{J}$ (ed.) Plant parasitic nematodes in subtropical and tropical agriculture, CABI Publishing, cap. 8, p. 259-318.

Tian BY, Yang JK, Zhang KQ (2007) Bacteria used in the biological control of plant-parasitic nematodes: Populations, mechanisms of action, and future prospects. FEMS Microbiology Ecology 61:197-213.

Vaz MV, Canedo EJ, Vieira BS, Lopes EA (2011) Controle biológico de Meloidogyne javanica e Meloidogyne incognita com Bacillus subtilis. Perquirere 8:203-212. 